\title{
The Development of Science Student Worksheet Based on Education for Environmental Sustainable Development to Enhance Scientific Literacy
}

\author{
Anita Ekantini*, Insih Wilujeng \\ Department of Science Education Postgraduate Program, Yogyakarta State University, Indonesia
}

Copyright(C2018 by authors, all rights reserved. Authors agree that this article remains permanently open access under the terms of the Creative Commons Attribution License 4.0 International License

\begin{abstract}
Indonesia is a country that has abundant renewable energy sources, one of which is hydropower that can be utilized as an alternative energy source. However, fossil energy remains as major supplier of energy needs in all sectors of activity. The Education for Environmental Sustainable Development (EESD) approach can be applied in science education to prepare learners with environmental knowledge, especially energy, so students can participate actively in solving various energy issues in the environment. EESD is suitable to be trained to students using science student worksheet. The objectives of this research were: (1) to develop EESD-based science student worksheet that is theoretically valid and (2) to know the effectiveness of science student worksheet that is developed to increase scientific literacy. This research used 4-D Thiagarajan development model which includes Define, Design, Develop, and Disseminate stages. The findings of this study indicated that science student worksheet with EESD approach were: (1) theoretically valid according to validator with value A (very good category), and (2) effective to increase student scientific literacy.
\end{abstract}

Keywords Alternative Energy, Education for Environmental Sustainable Development, Science Education, Scientific Literacy, Science Student Worksheet

\section{Introduction}

Energy becomes a necessity that cannot be separated from humans. The need for this energy continues to increase along with the development of civilization. Energy demand grows about $10 \%$ per year [1]. Fossil fuels are one of the energy sources that are currently the main supplier of energy needs in all sectors of activity (94\%), which consist of fuel oil (41\%), gas (23\%), and coal (30\%).
However, fossil energy is a non-renewable energy source, so it will eventually run out. As a natural resource, energy must be maximally utilized for the welfare of the community and its management should be based on the principle of sustainable development [2]. Minister of Energy and Mineral Resources, Sudirman Said, said Indonesia's oil resources are only enough for 12 more years [3]. In fact, Indonesia is a country that has abundant renewable energy sources, namely hydro power, wind energy, geothermal, biogas, marine energy, solar energy, and others that can be utilized as alternative energy. However, the utilization of renewable energy is only about $6 \%$ [4]. Therefore, it is urgent to promote the use of renewable energy sources to replace fossil energy. One of alternative energy sources is water. Water is an environmentally friendly source of renewable energy. It can potentially be utilized as an alternative energy source because most of the regions in Indonesia are surrounded by waters.

It is important to instill awareness to young generation of the condition and potential of the environment; one of them is through education. Learners' awareness of environmental issues is in line with the level of knowledge and skills of environmental scientific literacy [5]. Scientific literacy is the ability to engage with science-related issues and with science ideas, as caring citizens [6]. Scientific literacy is essential to develop the ability to be creative in utilizing science in everyday life or in careers, to solve problems, and to make decisions so as to improve the quality of life [7]. Pisa states there are four dimensions of scientific literacy, namely contexts, knowledge, competencies, and attitudes [6]. In this study, the researchers restricted the dimensions to only competencies and contexts. The context of scientific literacy is emphasized in everyday life that focuses on environmental quality. Pisa's [6] scientific literacy competences are (1) explaining phenomena scientifically, (2) evaluating and designing scientific inquiry, and (3) Interpreting data and 
evidence scientifically.

EESD approach is very important in education to instill science knowledge and skills, so that students are sensitive to various environmental problems especially in Indonesia. EESD is part of Education for Sustainable Development (ESD). ESD is a vast and lifelong effort that challenges every individual, institution and community to view tomorrow as a day for all of us, or it will not belong to anyone [8]. Hastuti (2009) argues that ESD is a new paradigm in the field of education that gives awareness and ability to all the main people of young generation to contribute significantly to sustainable development [9]. Gadotti states the concept of sustainability is an excellent component of education because environmental preservation depends on ecological awareness, which depends on the educational process [10]. UNESCO (2012) states that sustainability perspective represents economic, social, cultural and environmental problems in pursuit of economic development, human welfare and ecosystem integrity [11]. EESD is a concept of Education for Sustainable Development that focuses on environmental dimensions. It can be said that Education for Environmental Sustainable Development (EESD) is education as an effort to change behavior and lifestyle through awareness of natural resources, sensitive physical environment, impact of human activities, and decision-making related to environmental sustainability in the future.

Redman states that the competences of sustainability include (1) system thinking and understanding of interconnectedness, (2) longterm, foresighted reasoning, and strategizing, (3) stakeholder engangement and group collaboration, (4) action orientation and change-agent skills [12]. Frisk \& Larson (2011) expressed the competence in education for sustainable development is (1) systems thinking and an understanding of interconnectedness, (2) long-term, foresighted thinking, (3) stakeholder engagement and group collaboration, (4) action-orientation and change-agent skills [13].

Student worksheet is sheets containing tasks that students must do. Student worksheets will contain at least: title, basic of competence to be achieved, completion time, equipment / materials needed to complete the task, brief information, work steps, tasks to be done, and reports to be done [14]. According to Prastowo (2013) student worksheet is a printed material in the form of sheets of paper containing materials, summaries, and instructions on the implementation of learning tasks that must be done by student, which refers to the basic competencies that must be achieved [15]. Criteria for assessment or evaluation of instructional materials according to Depdiknas can be used as guidance for evaluation of science student worksheet, including the content feasibility component, language component, display component and graphical component [14].

Based on the explanation that has been put forward, it is very necessary to conduct research on the development of science student worksheet based on education for environmental sustainable development to improve scientific literacy of junior high school students. Oghenekohwo \& Frank-Oputu state that literacy is a part of promoting sustainable development [16].

\section{Materials and Methods}

\subsection{Type of the Research Method}

This research was Research and Development (R\&D) that was intended to produce EESD-based science student worksheet whose theme is "Water as Alternative Energy Source" and to know the increase in the scientific literacy of junior high school students after learning using science student worksheet that was developed. This research used the design of 4-D development model by Thiagarajan, covering the steps of Define, Design, Develop, and Disseminate [17].

\subsection{Subject of the Research}

The subjects of this research were 60 students from grade VII Pandak 1 Junior High Scholl in the first semester of 2017/2018 school year. The subjects are consisting of 30 students of VII C as experimental class and 30 students of VII D as control class for main field testing.

\subsection{Development Procedure}

The development procedure of the science student worksheet was adapted from the development design of Thiagarajan 4-D development, covering the steps of define, design, develop, and disseminate. The first step was defined to collect various required information in research and development activities. Information gathering was conducted through literature studies and field studies.

The second step was design where the researchers made a product design consisting of the selection of media form and the preparation of media concept, as well as made draft I. The main objective of this step was to prepare the prototype of EESD-based science student worksheet.

The third step was develop, that is to produce EESD-based science student worksheet which had been revised based on experts suggestion. Steps taken at this stage were expert appraisal and developmental testing. Expert appraisal was validation and product assessment by validators. In this study, validation was done by four experts consisting of two expert lecturers and two science teachers. The materials of the validation instrument for the experts can be seen in Table 1.

Developmental testing consisted of a development test conducted twice, limited testing and main field testing. After the product was revised and produced a ready 
product to test, science student worksheet developed was conducted limited testing to the students of class VII. The limited testing was tested to the students using questionnaire of students' response legibility. The materials for Questionnaire of Students' Response Legibility can be seen in Table 2. Questionnaire responses of students were prepared to determine learners' legibility response for science student worksheet developed. This questionnaire instrument was prepared using yes or no answers, making it easier for students to fill it. The results of this limited testing could be used to improve the science student worksheet developed. After the revision of science student worksheet, the product of development was used in main field testing.

Table 1. The Materials of the Validation Instrument of EESD-Based Science Student Worksheet

\begin{tabular}{|c|c|c|c|c|}
\hline No. & Rated Aspect & Indicator & $\begin{array}{c}\text { Number of } \\
\text { Item }\end{array}$ & $\begin{array}{c}\text { Item } \\
\text { Number }\end{array}$ \\
\hline \multirow{4}{*}{1.} & \multirow{4}{*}{$\begin{array}{l}\text { EESD approach } \\
\text { component }\end{array}$} & EESD emphasis on system thinking aspects & \multirow{4}{*}{4} & \multirow{4}{*}{1 to 4} \\
\hline & & EESD emphasis on foresighted thinking and strategizing aspects & & \\
\hline & & EESD emphasis on collaborating aspects & & \\
\hline & & EESD emphasis on the Action-orientation aspect & & \\
\hline \multirow{6}{*}{2.} & \multirow{6}{*}{$\begin{array}{l}\text { Content feasibility } \\
\text { component }\end{array}$} & Compatibility with essence competencies and basic competencies & \multirow{6}{*}{6} & \multirow{6}{*}{5 to 10} \\
\hline & & Compatibility with child development & & \\
\hline & & Compliance with the needs of teaching materials & & \\
\hline & & The truth of substance from learning materials & & \\
\hline & & Benefits for additional insights & & \\
\hline & & Conformity with moral values and social values. & & \\
\hline \multirow{4}{*}{3.} & \multirow{4}{*}{$\begin{array}{l}\text { Language } \\
\text { component }\end{array}$} & Legibility & \multirow{4}{*}{4} & \multirow{4}{*}{11 to 14} \\
\hline & & Clarity of Information & & \\
\hline & & Conformity with the good and true Indonesian language & & \\
\hline & & Effective and efficient use of language (clear and concise) & & \\
\hline \multirow{5}{*}{4.} & \multirow{5}{*}{ Display component } & Clarity of goals and indicators to be achieved. & \multirow{5}{*}{5} & \multirow{5}{*}{15 to 19} \\
\hline & & The order of display & & \\
\hline & & Giving motivation or attraction. & & \\
\hline & & Interaction (giving stimulus and response) & & \\
\hline & & Completeness of Information & & \\
\hline \multirow{4}{*}{5.} & \multirow{4}{*}{$\begin{array}{l}\text { Graphical } \\
\text { component }\end{array}$} & Font usage; type and size & \multirow{4}{*}{4} & \multirow{4}{*}{20 to 23} \\
\hline & & Layout & & \\
\hline & & Illustrations, pictures, and photos & & \\
\hline & & Appearance design & & \\
\hline
\end{tabular}

Table 2. Questionnaire Materials of Students' Response Legibility

\begin{tabular}{|c|c|c|c|}
\hline No. & Aspect & Indicator & Item Number \\
\hline 1 & Image Display & Images display is clear and interesting. & 1 \\
\hline 2 & Student Worksheet Display & Student worksheet display is interesting. & 2,3 \\
\hline 3 & Image, Tables and Questions Layout & $\begin{array}{c}\text { The layout of images, tables, and questions layout } \\
\text { is displayed clearly and appealingly. }\end{array}$ & 4 \\
\hline 4 & $\begin{array}{c}\text { Title, Command, Picture, Table, and } \\
\text { Question Display }\end{array}$ & $\begin{array}{c}\text { Titles, commands, drawings, tables, and questions } \\
\text { are clearly displayed. }\end{array}$ & $5,6,7$ \\
\hline 5 & Language Usage & $\begin{array}{c}\text { The language used in student worksheet is clear } \\
\text { and easy to understand. }\end{array}$ & 8 \\
\hline 6 & Font Size & Font size is appropriate. & 10 \\
\hline 7 & Clarity of Information & The information is presented clearly. & 9 \\
\hline
\end{tabular}


To analyze the effectiveness of science student worksheet in improving scientific literacy, a test was done to the students' scientific literacy ability. The trial test of science literacy was done by one class in grade VIII junior high school students who had learnt Energy material. The purpose of these trials was to obtain a valid empirical science literature, so that the scientific literacy question was ready to be used on the main field test.

Field tests were conducted using the experimental design of the Pretest-Posttest Control Group Design model. The research design can be seen in Table 3 . In this field test, researchers take samples of the two classes of class VII selected using cluster sampling method, one class as the experimental class and another as the control class. The experimental class uses EESD-based student worksheet on the learning process, while the control class uses the conventional student worksheet. Science Lesson with the theme "Water as Alternative Energy Source" conducted as many as three meetings with four activities. The topics for each activity can be seen in Table 4 .

The students' scientific literacy in the control class and the experimental class was measured before and after the learning process. The Increase in the scientific literacy between the control class and experimental class was compared to find out the effectiveness of the science student worksheet developed to improve students' scientific literacy. The aspect of scientific literacy assessment can be seen in Table 5 .

Table 3. Research Design

\begin{tabular}{|c|c|c|c|}
\hline Group & Pretest & Treatment & Posttest \\
\hline $\mathrm{E}$ & $\mathrm{Y}_{1}$ & $\mathrm{X}$ & $\mathrm{Y}_{2}$ \\
$\mathrm{~K}$ & $\mathrm{Y}_{1}$ & $\mathrm{Y}_{2}$ \\
\hline
\end{tabular}

Table 4. Topics of Learning Activities on Theme "Water as an Alternative Energy Source"

\begin{tabular}{|c|c|c|}
\hline Activity & Topic & Information \\
\hline $1^{\text {st }}$ & Energy in Human Life & $1^{\text {st }}$ meeting \\
\hline $2^{\text {nd }}$ & $\begin{array}{c}\text { Potential Water as } \\
\text { Alternative Energy Source }\end{array}$ & $2^{\text {nd }}$ meeting \\
\hline $3^{\text {rd }}$ & $\begin{array}{c}\text { Making a Simple } \\
\text { Waterwheel }\end{array}$ & Assignment \\
\hline $4^{\text {th }}$ & $\begin{array}{c}\text { Does Water Dam Have } \\
\text { Energy? }\end{array}$ & $3^{\text {rd }}$ meeting \\
\hline
\end{tabular}

Table 5. The Aspect of the Scientific Literacy Assessment

\begin{tabular}{|c|c|c|c|}
\hline No. & Rated Aspect & Indicator & $\begin{array}{c}\text { Item } \\
\text { Number }\end{array}$ \\
\hline \multirow{3}{*}{1.} & \multirow{3}{*}{$\begin{array}{l}\text { Explain the } \\
\text { phenomenon } \\
\text { scientifically }\end{array}$} & $\begin{array}{l}\text { Recognize questions } \\
\text { that may be } \\
\text { scientifically } \\
\text { investigated in the } \\
\text { given situation }\end{array}$ & 1,2 \\
\hline & & $\begin{array}{l}\text { Finding information } \\
\text { and identify keywords }\end{array}$ & 3,4 \\
\hline & & $\begin{array}{l}\text { Identify keywords in } \\
\text { scientific investigation }\end{array}$ & $5,6,7$ \\
\hline \multirow{3}{*}{2.} & \multirow{3}{*}{$\begin{array}{l}\text { Evaluate and } \\
\text { design scientific } \\
\text { inquiry }\end{array}$} & $\begin{array}{l}\text { Application of science } \\
\text { knowledge in the given } \\
\text { situations }\end{array}$ & $8,9,10$ \\
\hline & & $\begin{array}{l}\text { Describe the } \\
\text { phenomenon and } \\
\text { predict changes. }\end{array}$ & 11,12 \\
\hline & & $\begin{array}{l}\text { Introduction and } \\
\text { identification of } \\
\text { descriptions, } \\
\text { explanations and } \\
\text { predictions as } \\
\text { appropriate }\end{array}$ & 13,14 \\
\hline \multirow{3}{*}{3.} & \multirow{3}{*}{$\begin{array}{l}\text { Interpret data and } \\
\text { evidence } \\
\text { scientifically }\end{array}$} & $\begin{array}{l}\text { Interpreting the } \\
\text { scientific findings as } \\
\text { evidence for a } \\
\text { conclusion }\end{array}$ & 15,16 \\
\hline & & $\begin{array}{l}\text { Stating evidence and } \\
\text { decisions with } \\
\text { sentences, diagrams or } \\
\text { other representational } \\
\text { forms }\end{array}$ & 17,18 \\
\hline & & $\begin{array}{l}\text { Being able to describe a } \\
\text { clear and logical } \\
\text { relationship between } \\
\text { evidence and } \\
\text { conclusions or } \\
\text { decisions }\end{array}$ & 19,20 \\
\hline 4. & $\begin{array}{l}\text { Understanding of } \\
\text { environmental } \\
\text { issues }\end{array}$ & $\begin{array}{l}\text { Understand the } \\
\text { environmental issues } \\
\text { presented in the article }\end{array}$ & 21,22 \\
\hline
\end{tabular}


Table 6. The Observation Sheet Materials of the Learning Implementation with the EESD Approach

\begin{tabular}{|c|c|c|}
\hline Meeting & Aspects of Assessment & $\begin{array}{c}\text { Amounts of } \\
\text { Indicators }\end{array}$ \\
\hline \multirow{4}{*}{$1^{\text {st }}$} & Systems Thinking Aspect & 4 \\
\cline { 2 - 3 } & $\begin{array}{c}\text { Foresighted Thinking and } \\
\text { Strategizing Aspect }\end{array}$ & 6 \\
\cline { 2 - 3 } & Collaborating Aspect & 4 \\
\cline { 2 - 3 } & Action-Orientation Aspect & 1 \\
\hline \multirow{3}{*}{$2^{\text {nd }}$} & Systems Thinking Aspect & 5 \\
\cline { 2 - 3 } & $\begin{array}{c}\text { Foresighted Thinking and } \\
\text { Strategizing Aspect }\end{array}$ & 5 \\
\cline { 2 - 3 } & Collaborating Aspect & 4 \\
\hline $3^{\text {rd }}$ & Action-Orientation Aspect & 8 \\
\hline
\end{tabular}

The Implementation of learning using EESD approach was assessed using observation sheet of learning implementation. The filling of the observation sheet for the EESD approach was carried out by the observer who understood the rubric or assessment guide, so that they can use the observation sheet correctly. Aspects contained in the observation sheet of the learning implementation in accordance with the characteristics of the EESD approach. The materials of the observation sheet of the learning implementation with the EESD approach can be seen in Table 6 .

The fourth step was disseminate that had done by distribution to teachers and students. In this research, the dissemination stage was limited to the school where the research was conducted.

\subsection{Data Analysis Techniques}

The data collection techniques in this study were questionnaires, tests and observation sheets. The questionnaire instrument was used in the validation of science student worksheet by experts and students' response legibility. The test was done with the instrument in the form of essay test of scientific literacy. The test instrument was used to measure students' scientific literacy. The observation sheet was used to determine the implementation of learning using the EESD approach.

The data analysis in this research was validation analysis of science student worksheet, analysis of students' response legibility, analysis of learning implementation with EESD approach, and product effectiveness analysis to increase students' scientific literacy. Expert appraisal analysis of science student worksheet was descriptive qualitative and quantitative analysis. Qualitative analysis was used to analyze the suggestions from the expert. Suggestions from the experts could be used to fix science student worksheet. The quantitative analysis was used to analyze the assessment data from expert. Validation values obtained on each point of assessment were then summed as actual score (X). This quantitative actual score was converted to qualitative value by referring to the conversion of the score to a scale of five. This was to determine the feasibility of the quality of the science student worksheet developed. The reference of converting the score to the scale of five is shown in Table 7.

The value of product feasibility in this research would be determined with minimum value of " $\mathrm{C}$ " with enough categories. Thus, if the results of the assessment by experts and science teachers gave the final result of at least "C", the developed science student worksheet is feasible to use.

Students' response legibility was used to analyze the response of student for the science student worksheet legibility. The result from student' response legibility can be used to improve the quality of science student worksheet developed. At the end of the questionnaire was also provided a comment column to analyze students' opinions on science student worksheet developed.

Implementation of learning using EESD approach was used to analyze the success of EESD approach applied in the learning process. Assessment of the percentage of EESD approach implementation was obtained from the observation sheet. Percentage of learning can be calculated by the equation as follows.

$\%$ implementation $=$

$\frac{\text { Laspects of learning that are accomplished }}{\text { Loverall aspect }} \times 100 \%$

Percentage of learning implementation was then converted into qualitative data using criteria from Widoyoko [18]. The percentage and category of learning implementation can be seen in Table 8 .

The product effectiveness in increasing scientific literacy was analyzed using gain score and independent sample t-test. Gain score was used to know the increase in scientific literacy. The calculation of gain score could be done with the following equation.

$$
\text { Gain score }=\frac{\text { posttest score-pretest score }}{\text { maximum score-pretest score }}
$$

Table 7. Conversion of the Actual Score into a Five Scale Score

\begin{tabular}{|c|c|c|c|}
\hline No. & Interval & Mark & Category \\
\hline 1. & $\mathrm{X}>\mathrm{xi}+1.80 \mathrm{Sbi}$ & $\mathrm{A}$ & Very Good \\
\hline 2. & $\mathrm{xi}+0.60 \mathrm{Sbi}<\mathrm{X} \leq \mathrm{xi}+1.80 \mathrm{Sbi}$ & $\mathrm{B}$ & Good \\
\hline 3. & $\mathrm{xi}-0.60 \mathrm{Sbi}<\mathrm{X} \leq \mathrm{xi}+0.60 \mathrm{Sbi}$ & $\mathrm{C}$ & Enough \\
\hline 4. & $\mathrm{xi}-1.80 \mathrm{Sbi}<\mathrm{X} \leq \mathrm{xi}-0.60 \mathrm{Sbi}$ & $\mathrm{D}$ & Poor \\
\hline 5. & $\mathrm{X}<\mathrm{xi}-1.80 \mathrm{Sbi}$ & $\mathrm{E}$ & Very poor \\
\hline
\end{tabular}

Source: [18]

Table 8. Percentage and Category of Learning Implementation

\begin{tabular}{|c|c|c|}
\hline No. & Percentage & Category \\
\hline 1. & $80 \leq \mathrm{X} \leq 100$ & Very Good \\
\hline 2. & $60 \leq \mathrm{X}<80$ & Good \\
\hline 3. & $40 \leq \mathrm{X}<60$ & Enough \\
\hline 4. & $20 \leq \mathrm{X}<40$ & Poor \\
\hline 5. & $0 \leq \mathrm{X}<20$ & Very Poor \\
\hline
\end{tabular}

Source : [18]

Independent sample t-tes was used to distinguish scientific literacy gain between the experimental and the 
control class. In addition, there would be a significant difference between the experimental class and the control class if the level of significance in the independent sample t-tes analysis was less than 0.05 or sig.2-tailed $<0.05$. The hypothesis of this study is as follows.

$\mathrm{H}_{0}$ : There is no significant difference in the student's scientific literacy scores between experimental class and control classes

$\mathrm{H}_{1}$ : There is a significant difference in students scientific literacy score between the experimental class and the control class

Before analyzed using independent sample t-test, prerequisite tests were performed that included normality and homogeneity tests. Normality test was intended to determine whether the data from each variable is normally distributed or not. The requirement for normally distributed data is probability or (Sig.) > 0.05 [19]. Homogeneity test aims to know the sample comes from a homogeneous population or not by comparing the two variances. The data requirement derived from the homogeneous population is probability (Sig.) $>0.05$ and if the probability (Sig.) $<0.05$ then the data is not homogeneous [19].

\section{Results and Discussion}

Science student worksheet was validated by four experts, consisting of two lecturers and two science teachers. Assessment of the validator included five components namely the EESD approach component, the content feasibility component, the language component, the display component and the graphical component.

Assessment data from validator were qualitative dan quantitative data. The qualitative data were in the form of suggestions from the validator to revise science student worksheet. The quantitative data were score assessment data from the validator to the science student worksheet. The validators provided an assessment by filling out a five-scale questionnaire. Validator suggestion for student worksheet developed can be seen in Table 9, while assessment data from validator are shown in Table 10 . Table 9 shows the suggestion for improving student worksheet from four validators.

Based on the data in Table 10, the mean score of validation results from expert lecturers and science teachers can be obtained. The mean scores given by the validators are presented in the diagram as shown in Figure 1.

Table 9. Validator Suggestions for Student Worksheet

\begin{tabular}{|c|c|c|c|}
\hline No. & Validator & \multicolumn{1}{|c|}{ Suggestions } \\
\hline 1 & Lecturer 1 & $\bullet \begin{array}{l}\text { the image should be a personal } \\
\text { document } \\
\text { cover is equipped with an image of } \\
\text { the river } \\
\text { diagram competed with original } \\
\text { image }\end{array}$ \\
\hline 2 & Lecturer 2 & $\bullet \begin{array}{l}\text { before the material is added } \\
\text { apperception } \\
\text { title writing using easy-to-read } \\
\text { fonts }\end{array}$ \\
\hline 3 & Teacher 1 & $\bullet \begin{array}{l}\text { background color is replaced with a } \\
\text { more soft color }\end{array}$ \\
\hline 4 & Teacher 2 & $\bullet$ & $\begin{array}{l}\text { background color is replaced with a } \\
\text { more soft color }\end{array}$ \\
\hline
\end{tabular}

Table 10. Assessment Data from Validator

\begin{tabular}{|c|c|c|c|c|c|c|}
\hline \multirow{2}{*}{ No. } & \multirow{2}{*}{ Component } & \multicolumn{5}{|c|}{ Assessment Score } \\
\cline { 2 - 6 } & & Lecturer 1 & Lecturer 2 & Teacher 1 & Teacher 2 & Mean \\
\hline 1. & EESD approach component & 20 & 20 & 20 & 20 & 20.00 \\
\hline 2. & Content feasibility component & 30 & 30 & 26 & 28 & 28.50 \\
\hline 3. & Language component & 20 & 20 & 20 & 20 & 20.00 \\
\hline 4. & Display component & 23 & 21 & 20 & 23 & 21.75 \\
\hline 5. & Graphical component & 18 & 17 & 16 & 18 & 17.25 \\
\hline
\end{tabular}




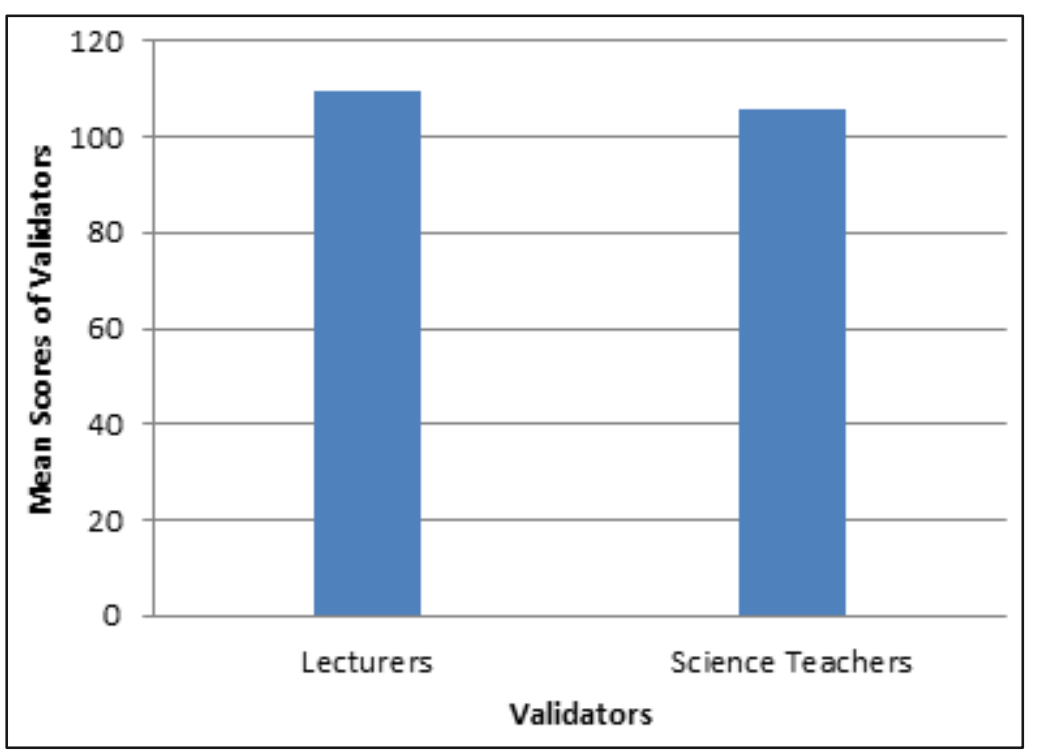

Figure 1. Diagram of Mean Scores Given by the Validators

Table 11. Marking Score Conversion of Assessment Data from Validator

\begin{tabular}{|c|c|c|}
\hline Mark & Interval & Category \\
\hline $\mathrm{A}$ & $\mathrm{X} \geq 96.59$ & Very Good \\
\hline $\mathrm{B}$ & $78.20<\mathrm{X} \leq 96.59$ & Good \\
\hline $\mathrm{C}$ & $59.80<\mathrm{X} \leq 78.20$ & Enough \\
\hline $\mathrm{D}$ & $41.41<\mathrm{X} \leq 59.80$ & Poor \\
\hline $\mathrm{E}$ & $\mathrm{X}<41.41$ & Very Poor \\
\hline
\end{tabular}

The mean score obtained from the four experts was then converted to a scale of five as shown in Table 2. Marking score conversion of assessment data from validator shown in Table 11.

Based on the expert assessment, the mean score of all components is 107.50. If converted in accordance with Table 2, the science student worksheet developed gets grade A with very good category. Science student worksheet is concluded to be valid and feasible to be used in learning process if the value obtained from the expert assessment is at least $\mathrm{C}$. Thus we can conclude from the result that science student worksheet is theoretically valid according to the experts.

The science student worksheet that had been validated and revised in accordance with the validator's suggestion was then tested in the field. The development testing was conducted to the students of grade VII Junior High School in order to know the effectiveness of the science student worksheet developed. The development testings were conducted twice, namely limited testing and main field testing. The limited testing was in the form of the responsiveness of the science student worksheet according to the students. The limited testing was done to the students of grade VII, consisting of nine students. The results of this limited testing can be used to improve the developed science student worksheet. Analysis results show that $100 \%$ of students answered yes on each statement on the questionnaire. Examples of student comments are as follows.

"Science student worksheet is very interesting"

"How glad to learn using science student worksheet"

"Learning science becomes easy with science student worksheet"

After limited testing was done, then the main field testing was conducted using the product of the development. The material was delivered using EESD approach. After the main field testing, the product was revised to obtain the final product.

The implementation of EESD approach in science learning was seen from the percentage of learning implementation. Based on the analysis result, it was found that the percentage of EESD approach attitudes by the teachers was $100 \%$ and by the students was $95 \%$. According to the criteria in Table 8 , it is included as a very good category.

To find out about the effectiveness of the science student worksheet developed on the increase in student's scientific literacy, pre-test and post-test were given. There were 10 essay items to measure the student's scientific literacy. The students were given pre-test before learning using the EESD-based science student worksheet to know the early scientific literacy of the students. After the learning process using the science student worksheet, the students were given post-test.

Treatment of pre-test and post-test was also given to the control class using conventional science student worksheet. From the score of the pre-test and post-test, the scientific literacy gain of the students in both the experimental and control class was known. The gain of scientific literacy of the experimental and control class can be seen in Table 11. The results showed that the highest gain score of scientific literacy was found in the 
experimental class, while the lowest gain score was in the control class. The results also showed that the average gain score of the students' scientific literacy in the experimental class was higher than in the control class. The diagram of the gain scores of both the experimental class and control class is shown in Figure 2. From the diagram in Figure 2, it can be seen that the gain score of the experimental class is higher than that of the control class.

Table 12. Gain Value of Scientific Literacy

\begin{tabular}{|c|c|c|c|c|c|}
\hline Groups & N & $\begin{array}{c}\text { Highest } \\
\text { Score }\end{array}$ & $\begin{array}{c}\text { Lowest } \\
\text { Score }\end{array}$ & Average & $\begin{array}{c}\text { Standar } \\
\text { Deviasi }\end{array}$ \\
\hline Experiment & 30 & 0.90 & 0.18 & 0.48 & 12.20 \\
\hline Control & 30 & 0.71 & 0.00 & 0.32 & 12.42 \\
\hline
\end{tabular}

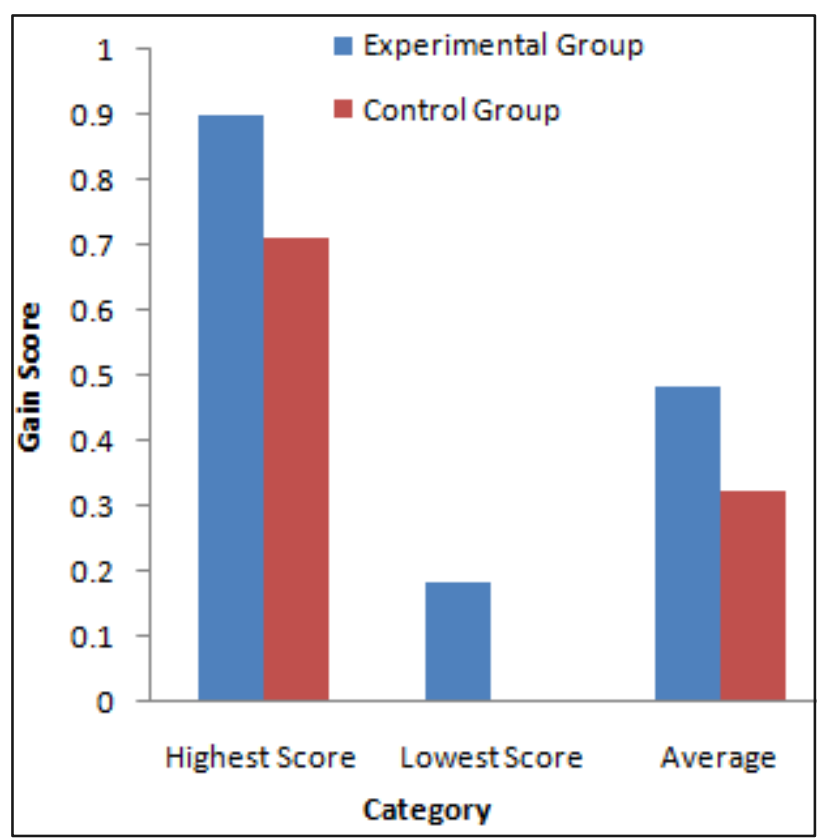

Figure 2. Diagram of Students' Gain Score in Scientific Literacy

Table 13. Test Prerequisite Hypothesis

\begin{tabular}{|c|c|c|}
\hline Prerequisite Test & \multicolumn{2}{|c|}{ Significance Value } \\
\hline Normality test & $\begin{array}{l}\text { Experiment } \\
\text { Control }\end{array}$ & $\begin{array}{l}: 0.200 \\
: 0.200\end{array}$ \\
\hline Homogeneity Test & \multicolumn{2}{|c|}{0.560} \\
\hline
\end{tabular}

Table 14. Statistic Independent Sample T-Test

\begin{tabular}{|c|c|}
\hline Variable & Sig.(2-tailed) \\
\hline Scientific Literacy & 0.001 \\
\hline
\end{tabular}

The gain of scientific literacy of each student in the experimental class and control class was analyzed using an independent sample t-test at the significance level of $5 \%$. Prior to analysis by independent sample t-test, some prerequisite tests were performed that included normality and homogeneity tests. The prerequisite test results can be seen in Table 13.

The gains of scientific literacy post-test and pre-test scores on both the experimental class and control class were then compared using an independent sample t-test. There was a significant difference in the scientific literacy between the experimental class and the control class if the sig. (2-tailed) $<0,05$. The result of independent statistical sample t-test is shown in Table 14.

According to the statistical independent sample t-test on scientific literacy, the gain of the significance is 0.001 or the sig. $<0.05$, so the $\mathrm{H}_{0}$ is rejected. Thus, with $95 \%$ confidence level, it can be said that science student worksheet based on education for environmental sustainable development is effective to improve the scientific literacy of junior high school students.

Science student worksheet based on education for environmental sustainable development was designed to help students improve their scientific literacy, so they can apply their knowledge in their daily life. As mentioned previously, the gain score of the experimental class is higher than that of the control class, so it can be concluded that learning using EESD-based science student worksheet improves scientific literacy.

Guevara (2015) states that Science literacy as outcomes of integrating sustainable development concepts and principles in coursework of general ecology was investigated [20]. The findings of that study indicate that there is a statistically significant improvement in students' scientific literacy upon the completion of the course.

EESD approach was applied in education to improve our views, attitude and knowledge towards the environment. This research shows that science student worksheet based on EESD was proven to improve scientific literacy, in this research especially in energy matter. ESD framework with the science learning has a great potential to help the pupils to develop their educational skills [21]. Sustainable education is highly connected to the professions involved in the development environment, as they play a role in decreasing the consumption of natural resources [22]. Environmental education for sustainable development is arising as an important approach to promote the students to conserve and keep the natural environment in their environment [23].

\section{Conclusions}

In this article we have presented the development of EESD-based science student worksheet. The development procedure was adapted from the design of Thiagarajan 4-D model, included the steps of define, design, develop, and disseminate. EESD-based science student worksheet was a new revolution to help student understanding about their environment and actively participate in maintaining the environment, so the environment can be utilized for sustainability. Students are the young generation that is very appropriate to be an environmental agent to provide 
change in the future. We have also described that EESD-based science student worksheet theoretically and empirically valid to increase student scientific literacy. According to the findings, the students using EESD-based science student worksheet have higher score in scientific literacy than those who didn't use EESD-based science student worksheet. EESD-based science student worksheet facilitated students with EESD characteristics of EESD included: Systems Thinking, Foresighted Thinking and Strategizing, Collaborating, and Action-Orientation. This character of EESD helped students in building scientific literacy. Based on the findings of this research, it is useful for teachers to use science EESD-based science student worksheet to improve student's scientific literacy. Teachers can modified this science student worksheet as the condition of student and environment.

\section{Acknowledgements}

The researchers would like to thank to the Yogyakarta State University for supporting the researcher to do this research.

\section{REFERENCES}

[1] Ansori, M. (2014). Tiap Tahun Kebutuhan Energi Naik Hingga 10\% - Kalahkan Pertumbuhan Ekonomi Nasional. Retrieved from http://www.neraca.co.id

[2] Elinur, Priyarsono, Mangara Tambunan., et al. Perkembangan Konsumsi dan Penyediaan Energi dalam Perekonomian Indonesia. Indonesian Journal of Agricultural Economics (IJAE), Vol.2, No.1, 97-119, 2010.

[3] Pratama, A. F. (2014, November 1). Cadangan Minyak Indonesia Hanya untuk 12 Tahun Lagi. Retrieved from tribunnews.com

[4] Hutapea, M., Solusi Listrik Off-Grid Berbasis Energi Terbarukan di Indonesia: Kerangka Regulasi dan Program, Kementerian Energi dan Sumber Daya Mineral, Jakarta,2016.

[5] OECD, Organization for Economic Cooperation and Development. Assesing Scientific, Reading, Mathematical, and Financial Literacy A Framework for PISA 2015, OECD Publications, Paris, 2006.

[6] OECD, Organization for Economic Cooperation and Development. Assesing Scientific, Reading, Mathematical, and Financial Literacy A Framework for PISA 2015, OECD Publications, Paris, 2015.

[7] Holbrook, J. \& Rannikmae, M.The Meaning of Scientific Literacy. International Journal of Environmental \& Science Education, Vol.4, No.3, 275-288, 2009.

[8] Suprastowo, P. et al., Strategi Nasional Pelaksanaan ESD.
Jakarta, Puslitjaknov Balitbang Depdiknas, Jakarta, 2009.

[9] Hastuti, B. S. Pendidikan untuk Pengembangan Berkelanjutan (Education for Sustainable Development) dalam Perspektif PNFI. Jurnal PNFI, Vol.1, No.1, 45-56, 2009.

[10] Gadotti, Moacir. Reorienting Education Practices towards Sustainability. Journal of Education for Sustainable Development, Vol.4, No.2, 203 - 211, 2010.

[11] UNESCO, United Nations Educational, Scientific, and Cultural Organization. Education for Sustainable Development in Action Learning \& Training Tools: Sourcebook, UNESCO Education Sector, Paris, 2012.

[12] Redman, E. Advancing educational pedagogy for sustainability: Developing and implementing programs to transform behaviors. Internasiona Journal of Environment \& Science Education. Vol.8, No.1, 1-34, 2013.

[13] Frisk, E. \& Larson, K.L. Educating for Sustainability: Competencies \& Practices for Transformative Action. Journal of Sustainability Education, Volume 2, 2011.

[14] Depdiknas, Panduan Pengembangan Bahan Ajar, Depdiknas, Jakarta, 2008.

[15] Prastowo, A., Panduan Kreatif membuat Bahan Ajar Inovatif: Menciptakan Metode Pembelajaran yang Menarik dan Menyenangkan, Diva Press, Yogyakarta, 2013.

[16] Oghenekohwo, J.E. \& Frank-Oputu, E.A. Literacy Education and Sustainable Development in Developing Societies. International Journal of Education \& Literacy Studies, Vol.5, No.2, 126-131, 2017.

[17] Thiagarajan, S., Semmel, D. S., \& Semmel, M. I., Instructional Development for Training Teachers of Exceptional Children, Indiana University, Broomington, 1974.

[18] Widoyoko, E. P., Evaluasi Program Pembelajaran, Pustaka Pelajar, Yogyakarta, 2009.

[19] Triton, SPSS 16.0 Terapan, Riset Statistik Parametrik, ANDI, Yogyakarta, 2006.

[20] Guevara, C. A. Science Literacy, Awareness, and Attitude Enhancement through Integration of Sustainable Development Education in General Ecology. Iamure International Journal of Ecologi and Conservation, Vol.14, No.1, 2015.

[21] Eilks, I., Science Education and Education for Sustainable Development - Justifications, Models, Practices and Perspectives. Eurasia Journal of Mathematics, Science \& Technology Education, Vol.11, No.1, 149-158, 2015.

[22] Holdsworth S. \& Sandri.O. Sustainability Education and the Built Environment: Experiences from the Classroom. Journal for Education in the Built od environment, Vol.9, No.1, 48-68, 2015.

[23] Alexandar R. \& Poyyamoli G. The effectiveness of environmental education for sustainable development based on active teaching and learning at high school level-a case study from Puducherry and Cuddalore regions, India. Journal of Sustainability Education, Vol. 7, 2014. 